\title{
Penerapan Case-based Reasoning (CBR) pada Sistem Pakar Diagnosis Penyakit Tanaman Pangan
}

\author{
Minarni ${ }^{1 *}$, Wenda Handayani ${ }^{2}$, Nurhayati ${ }^{3}$ \\ Program Studi Teknik Informatika, Institut Teknologi Padang \\ Sumatera Barat, Indonesia \\ minarni1706@gmail.com,wendammd@gmail.com,nurhayatii301195@gmail.com
}

\begin{abstract}
ABSTRAK - This study discusses an expert system for diagnosing food plant diseases by applying Case-based Reasoning (CBR). CBR is a way of thinking computer reasoning by utilizing past knowledge to handle new cases. CBR resolves new cases by observing the old cases that are closest to the new cases. The diagnosis stage begins with entering new cases with their symptoms to be diagnosed into the system, after that calculating the similarity value of new cases with existing cases on a case basis with the nearest neighbor algorithm. Based on testing using test data with a similarity threshold of $70 \%$, the system produces performance with a sensitivity of $100 \%$ and an average accuracy rate of 76 , $74 \%$. This proves that the system works well for diagnosing food plant diseases (rice, cassava, corn, and peanuts).
\end{abstract}

\section{Keywords: Expert System, Diagnose, Disease, Food Plant, Case Based Reasoning}

ABSTRAK - Penelitian ini membahas tentang sistem pakar diagnosis penyakit tanaman pangan dengan menerapkan Case-based Reasoning (CBR). CBR merupakan cara berpikir bernalar komputer dengan memanfaatkan pengetahuan yang lalu untuk menangani kasus baru. CBR menyelesaikan kasus baru dengan mengamati kasus lama yang terdekat dengan kasus baru. Tahapan diagnosis diawali dengan mengentrikan kasus baru dengan gejalanya yang akan didiagnosis ke dalam sistem, setelah itu menghitung nilai kemiripan kasus baru dengan kasus-kasus yang ada pada basis kasus dengan algoritma nearest neighbor. Berdasarkan pengujian menggunakan data uji dengan ambang kemiripan sebesar $70 \%$ maka sistem menghasilkan performa dengan sensitivitas $100 \%$ dan tingkat akurasi rata-rata $76,74 \%$. Hal ini membuktikan bahwa sistem bekerja dengan baik untuk mendiagnosis penyakit tanaman pangan (padi, singkong, jagung, dan kacang tanah).

Kata Kunci: Sistem Pakar, Diagnosis, Penyakit, Tanaman Pangan, Case-Based Reasoning

\section{PENDAHULUAN}

Tanaman pangan merupakan semua tanaman yang didalamnya terdapat karbohidrat dan protein, sehingga menjadi sumber makanan pokok bagi mayoritas masyarakat Indonesia. Ada banyak jenis tanaman pangan diantaranya padi, singkong, jagung, dan kacang tanah [1]. Karena menjadi makanan pokok, maka perlu menjaga produktivitasnya. Terdapat banyak faktor yang berpengaruh pada produktifitas tanaman pangan, diantaranya yaitu hama dan penyakit yang menyerang tanaman. Beragam penyakit tanaman dengan ciri masingmasing penyakit yang mirip menyebabkan petani sulit mendiagnosa penyakit tersebut. Hal ini mengakibatkan turunnya produktifitas tanaman tersebut karena keterlambatan penanganannya. Untuk mendiagnosis adanya hama dan penyakit ini, maka dibutuhkan ahli atau pakar yang biasa dikenal dengan Penyuluh Pertanian Lapangan (PPL). Masing-masing daerah memiliki jumlah PPL yang berbeda. Dinas Pertanian Tanaman Pangan Provinsi Sumatera Barat Tahun 2015 memiliki sebanyak 234 orang PPL untuk tanaman pangan dan hortikultura. Sedangkan petani yang ada sebanyak 644.610 orang [2]. Berdasarkan data tersebut, tampak bahwa jumlah petani tidak sebanding dengan jumlah penyuluh. Selain dari sisi jumlah, para penyuluh juga dibatasi oleh waktu dan lokasi, sehingga dibutuhkan suatu sistem yang dapat membantu untuk mendiagnosis penyakit tanaman pangan. Salah satu solusi berupa sistem pakar (expert systems) yaitu aplikasi berbasis komputer yang berisikan cara berpikir dan bertindak seorang pakar atau ahli dalam menyelesaikan masalah [3]. Banyak metode yang digunakan untuk menentukan jenis penyakit tanaman, salah satunya dengan memanfaatkan data kasus yang tersimpan sebelumnya dikenal dengan Case-based Reasoning (CBR) [4]. Metode penalaran CBR berisi 4 tahap, yaitu retrieve, reuse, revise dan retain. Saat proses diagnosis memerlukan metode untuk menghitung tingkat kedekatan atau kemiripan suatu kasus dengan kasus yang ada sebelumnya. Salah satu metode digunakan yaitu metode Nearest Neighbor Similarity (NNS) [5].

Penelitian ini bertujuan untuk mengembangan sistem pakar diagnosis penyakit tanaman pangan yang menerapkan CBR dan NNS.

\section{DASAR TEORI}

Penelitian tentang sistem pakar di berbagai bidang telah banyak dilakukan, salah satu diantaranya pada bidang pertanian. Penelitian tentang sistem pakar untuk mendiagnosis penyakit pada tanaman menggunakan inferensi Forward Chaining telah menunjukkan hasil yaitu sistem yang dibangun telah dapat mendiagnosis hama dan penyakit tanaman [6], [7], [8], [9]. 
Selanjutnya penelitian dengan menerapkan berbagai metode inferensi yaitu metode certainty factor, dempster shafer, naïve bayes [10], [11], [12]. Hasil yang diperoleh dari metode certainty factor yaitu kepastian tanaman tersebut mengalami penyakit yang sebenarnya berdasarkan gejalagejala yang dialami. Sistem dengan metode naïve bayes menerapkan perhitungan probabilitas dan statistik. Pada perbandingan metode dempster shafer dengan Case-based Reasoning (CBR) diperoleh bahwa metode CBR lebih akurat dalam mengidentifikasi penyakit. Metode CBR dapat dimanfaatkan sebagai mesin inferensi dalam sistem pakar dengan cara mengingat kasus lampau, jika diperlukaan dapat digunakan kembali dan diadaptasi ke dalam kasus baru.
Berikut teori yang mendasari penelitian ini.

A. Sistem Pakar

Sistem pakar adalah suatu sistem yang memanfaatkan pengetahuan ahli atau pakar yang diterapkan ke dalam program komputer, bertujuan untuk membantu dalam memecahkan persoalan-persoalan yang membutuhkan keahlian [3]. Sistem pakar dibangun dengan struktur yang memuat lingkungan pengembangan (development environment) dengan fungsi sebagai tempat membangun komponen-komponen sistem pakar berupa knowledge base (basis pengetahuan), dan lingkungan konsultasi (consultation environment) merupakan media bagi pengguna untuk berkonsultasi dengan seorang pakar [3]. Gambar 1 menunjukkan struktur sistem pakar.

LINGKUNGAN PENGEMBANGAN

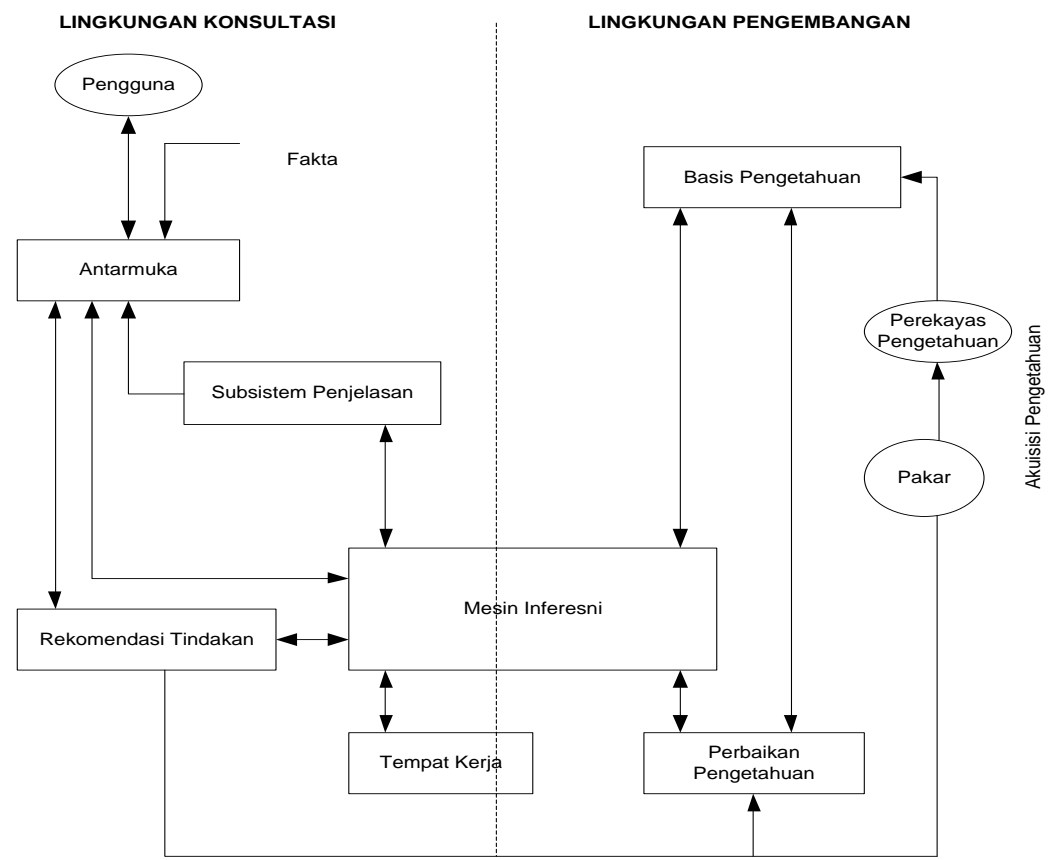

Gambar 1. Struktur Sistem Pakar

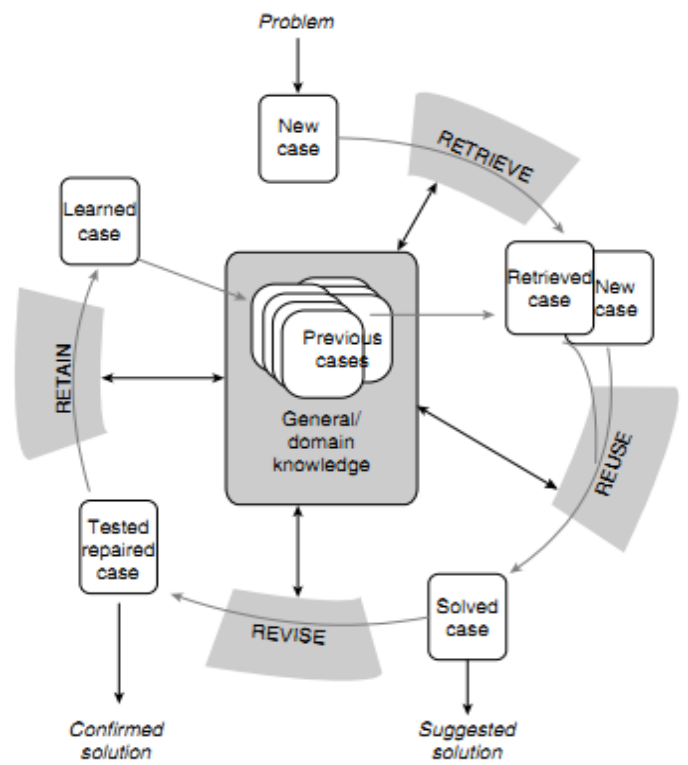

Gambar 2. Daur Case-based Reasoning (CBR) 


\section{B. Case-based Reasoning (CBR)}

Case-based Reasoning (CBR) merupakan proses dengan mempertimbang sebuah kasus masa lampau, yang akan digunakan kembali dan diadaptasi kedalam kasus baru [4]. Gambar 2 menampilkan siklus CBR.

Berikut uraian tahapan daur CBR: 1) Retrieve; Tahapan untuk menemukan kasus yang tersimpan pada basis kasus yang memiliki kesamaan dengan kasus yang baru. Pada tahap ini dilakukan proses mengidentifikasi kemiripan awal, penelusuran dan pemulihan serta pelaksanaan. 2) Reuse; Tahapan memanfaatkan pengetahuan, fakta, data, dan penjelasan dari kasus tersebut untuk menyelesaikan masalah. 3) Revise; Tahapan Revise yaitu tahapan untuk memantau atau memperbarui saran penyelesaian. 4) Retain; Tahapan mengarsipkan hasil tahapan sebelumnya, sehingga dapat digunakan menyelesaikan masalah pada saat dibutuhkan.

\section{Nearest Neighbor Similarity (NNS)}

Nearest Neighbor adalah satu dari banyak metode untuk mencari jarak terdekat dengan cara mengukur tingkat kemiripan dari setiap kasus yang tersimpan dalam basis kasus. Fungsi Similarity dirumuskan pada Persamaan (1) [5].

$$
\operatorname{Sim}(\mathrm{T}, \mathrm{Si})=\frac{\sum_{\mathrm{i}=1}^{\mathrm{n}} \mathrm{f}(\mathrm{T}, \mathrm{Si})^{*} \mathrm{wi}}{\sum_{\mathrm{i}=1}^{\mathrm{m}} \mathrm{wi}}
$$

Dimana $T=$ Kasus baru (target); $S=$ Kasus lama (source); $n=$ Jumlah atribut; $i=$ Jumlah atribut pada setiap kasus; $f=$ Fungsi similaritas atribut $i$ antara kasus $T$ dan kasus $S$; dan $w i=$ Bobot yang diberikan pada atribut ke- $i$.

Untuk mengukur kesamaan/kemiripan dengan memberikan 2 nilai yaitu 0 dan 1 . Untuk nilai 0 diberikan jika kedua kasus benar-benar tidak sama. Sebaliknya nilai 1 diberikan jika kedua kasus benar-benar mirip.

\section{Penyakit Tanaman Pangan}

Penelitian ini menggunakan data penyakit dari 4 jenis tanaman yaitu padi, singkong, jagung, dan kacang tanah. Masing-masing tanaman memiliki beberapa penyakit dengan gejala yang sama [1]. Nama masing-masing penyakit ditunjukkan pada Tabel 1 .

Tabel 1. Daftar Tanaman Pangan dan Penyakit

\begin{tabular}{llll}
\hline No & Tanaman Pangan & Penyakit & Gejala \\
\hline 1 & Padi & Bercak Coklat & Bercak berwarna kelabu \\
& & Blast & Bercak Hitam \\
& & Hawar Fusarium & Biji Hampa \\
& & $\ldots$. & $\ldots$. \\
& \multirow{4}{*}{ Singkong } & Jamur Akar Putih & Bentuk Daun Tidak Teratur \\
& & Hawar Bakteri & Umbi Membusuk \\
& & Layu Bakteri & Daun Mendadak Layu \\
3 & \multirow{4}{*}{ Jagung } & $\ldots$ & $\ldots$. \\
& & Lalat Bibit & Tanaman Kerdil \\
& & Virus Mozaik Kerdil & Tongkol Tidak Normal \\
& & Wereng Jagung & Daun Kuning \\
& \multirow{4}{*}{ Kacang Tanah } & $\ldots .$. & $\ldots$. \\
& & Bercak Daun & Daun Berwarna Kuning \\
& & Layu Sklerotium, & Bercak lebih kecil dan coklat \\
& & Layu Bakteri & Akar Busuk berwarna hitam \\
& & $\ldots$. & $\ldots$. \\
\hline
\end{tabular}

\section{METODOLOGI}

\section{A. Gambaran Sistem}

Secara umum sistem pakar diagnosis penyakit tanaman pangan dengan menerapkan CBR ditunjukkan pada Gambar 3. Sistem ini memiliki 3 hak akses, yaitu admin, petani, dan pakar. Admin bertugas mengelola sistem secara keseluruhan. Petani dapat memulai berkonsultasi melalui antarmuka modul konsultasi diawali dengan memilih salah satu tanaman pangan yang akan didiagnosis. Selanjutnya memilih gejala yang terdapat pada tanaman tersebut. Setelah itu sistem mulai melaksanakan tahapan retrieve dengan cara menghitung kedekatan gejala-gejala dengan kasus yang ada dalam basis kasus dengan metode NNS. Berikutnya tahapan reuse, yaitu memilih penyelesaian dengan mempertimbangkan kasus yang ada pada basis kasus yang memiliki similaritas tertinggi. Pada sistem ini memiliki threshold 0,7. Jika kasus baru dengan similaritas bernilai 0,7, maka penyelesaian kasus tersebut menggunakan penyelesaian sesuai dengan kasus yang tersimpan. Petani dapat melihat hasil diagnosis pada modul output. Tetapi, jika nilai similaritas <0,7, maka kasus tersebut dianggap tidak memiliki penyelesaian dan disimpan sebagai kasus baru yang nantinya akan ditinjau kembali oleh pakar (revise dan retain). Gambar 4 menunjukkan alur Case-based Reasoning (CBR). 


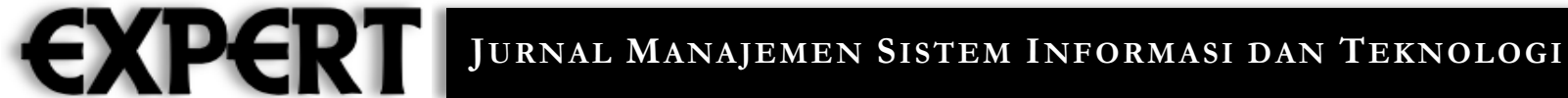

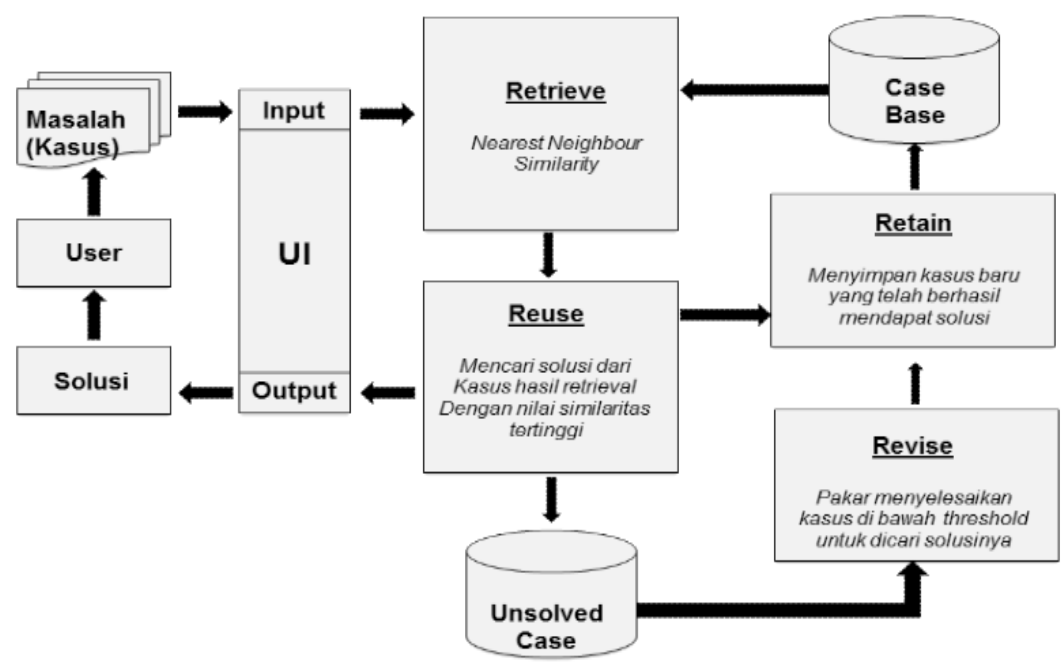

Gambar 3. Gambaran Sistem Pakar

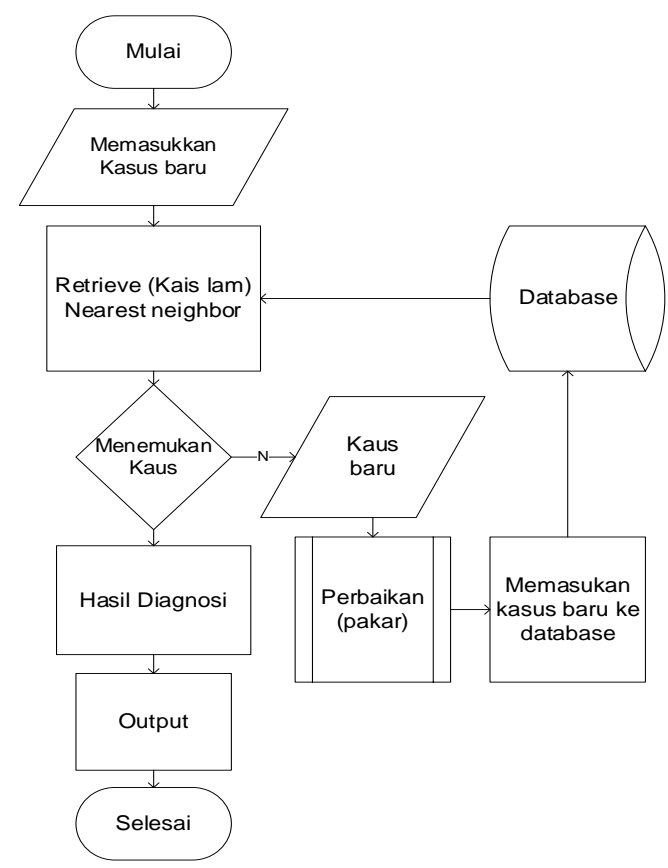

Gambar 4. Flowchart Program

B. Representasi Kasus

Representasi kasus menggunakan model frame yang terdiri dari Fitur gejala, penyakit dan solusi. Representasi ditampilkan pada Tabel 1. Untuk pembobotan gejala ditunjukkan pada Tabel 2 yang nantinya akan digunakan dalam mengukur nilai similaritas.

Tabel 2. Representasi Kasus

\begin{tabular}{|c|c|c|}
\hline Fitur & & Nilai \\
\hline \multicolumn{3}{|l|}{ Gejala } \\
\hline 1. & Daun Kering & $Y a=1$ \\
\hline 2. & Daun rontok & dan \\
\hline 3. & Bercak coklat muda pada daun & Tidak $=0$ \\
\hline 4. & Biji berkecambah sebelum waktunya & \\
\hline 5. & Akar busuk berwarna hitam & \\
\hline \multicolumn{3}{|c|}{ Dst..... } \\
\hline Penyaki & & 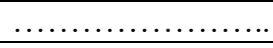 \\
\hline Solusi & & f.................. \\
\hline
\end{tabular}




\section{Inferensi Case-based Reasoning}

Proses inferensi diawali dengan tahap retrieval dilaksanakan dengan membandingkan gejala yang ada pada kasus baru dengan gejala yang tersimpan pada basis kasus, kemudian hasilnya akan digunakan untuk menghitung tingkat kesamaannya menggunakan Nearest
Neighbor. Tabel 3 menunjukkan salah satu kasus dengan gejala beserta bobot yang telah ditetapkan oleh pakar.

Contoh kasus penyakit tanaman kacang tanah, diawali dengan menghitung nilai Similarity kasus yang baru (T) dengan kasus yang tersimpan pada basis kasus (S) disajikan pada Tabel 3 .

Tabel 3. Fungsi Similaritas Kasus Baru (K2) dan Kasus Lama (S1)

\begin{tabular}{lllr}
\hline Kasus & Kasus Baru (T) (wi) & Kasus Lama (S1) & $\mathrm{f}(\mathrm{T}, \mathrm{Si})$ \\
\hline K2 & Bercak Coklat Pada daun (3) & Bercak Coklat Pada daun (3) & 1 \\
& Coklat kemerahan gelap permukaan atas & Coklat kemerahan gelap permukaan atas & 1 \\
& daun (3) & daun (3) & 1 \\
Daun Berwarna kuning (1) & Daun Berwarna kuning (1) & 1 \\
& Daun Kering (3) & Daun Kering (3) & 1 \\
& Daun Rontok (3) & Daun Rontok (3) & 0 \\
\hline
\end{tabular}

Perhitungan kemiripan/ similarity menggunakan Persamaan (1):

$$
\operatorname{Sim}(T, S i)=\frac{(1 \times 3)+(1 \times 3)+(1 \times 1)+(1 \times 3)+(1 \times 3)+(0 \times 3)}{3+3+1+3+3+3}=0,8125
$$

Hasil perhitungan diperoleh nilai kemiripan 0,8125 atau $81,25 \%$.

Langkah berikutnya dilakukan perhitungan seperti di atas untuk menentukan kemiripan (similarity) kasus K2 dengan 6 kasus yang sudah tersimpan dalam basis kasus. Hasil perhitungan dapat dilihat seperti Tabel 4.

Pada tahapan reuse penyelesaian diagnosis diberikan oleh kasus dengan nilai similarity tertinggi. Pada Tabel 4 diperoleh nilai similaritas tertinggi terdapat pada S1 yaitu penyakit bercak daun dengan nilai sebesar 0,8125 atau $81,25 \%$, sehingga solusi untuk penyakit bercak daun menjadi solusi yang direkomendasikan.

\begin{tabular}{ll} 
& Tabel 4. Nilai Similaritas \\
\hline Kasus & Nilai Similaritas CBR $(\%)$ \\
\hline K2-S1 & 81.25 \\
K2-S2 & 13.64 \\
K2-S3 & 0 \\
K2-S4 & 4.55 \\
K2-S5 & 0 \\
K2-S6 & 27.27 \\
\hline MAX & 81,25 \\
\hline
\end{tabular}

\section{Pengujian Sistem}

Untuk mengukur kinerja sistem, maka dilakukan evalusi dengan cara menghitung nilai sensitivitas dan akurasi dengan persamaan (2) dan (3) [13].

$$
\begin{aligned}
& \text { Sensitivitas }=\frac{T_{P}}{T_{P}+T_{N}} \\
& \text { Akurasi }=\frac{T_{P}+T_{N}}{T_{P}+F_{P}+T_{N}+F_{N}}
\end{aligned}
$$

Penjelasan:

$T_{P}=$ jumlah diagnosis positif/ benar untuk data uji positif $F_{P}=$ jumlah diagnosis negatif/ salah untuk data uji positif $T_{N}=$ jumlah diagnosis positif/ benar untuk data uji negatif $F_{N}=$ jumlah identifikasi negatif/salab untuk data uji negatif

\section{HASIL DAN PEMBAHASAN}

A. Implementasi Sistem

Untuk memulai konsultasi, pengguna memilih menu konsultasi yang terdiri dari sub menu padi, jagung, singkong dan kacang tanah. Pada halaman konsultasi Gambar 6, pengguna menuliskan nama dan memilih alamat, kemudian mulai memilih gejala-gejala yang dialami oleh tanamannya. Sistem akan mendiagnosis penyakit sesuai dengan gejala yang dipilih menggunakan CBR dan NNS. Gambar 7 dan Gambar 8 menampilkan hasil diagnosis. 


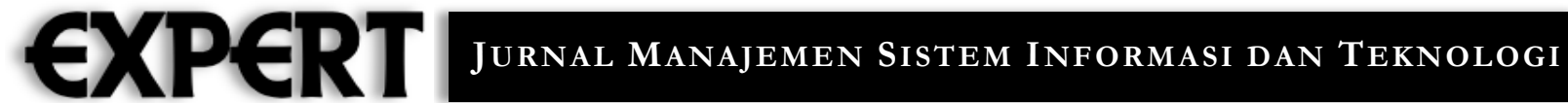

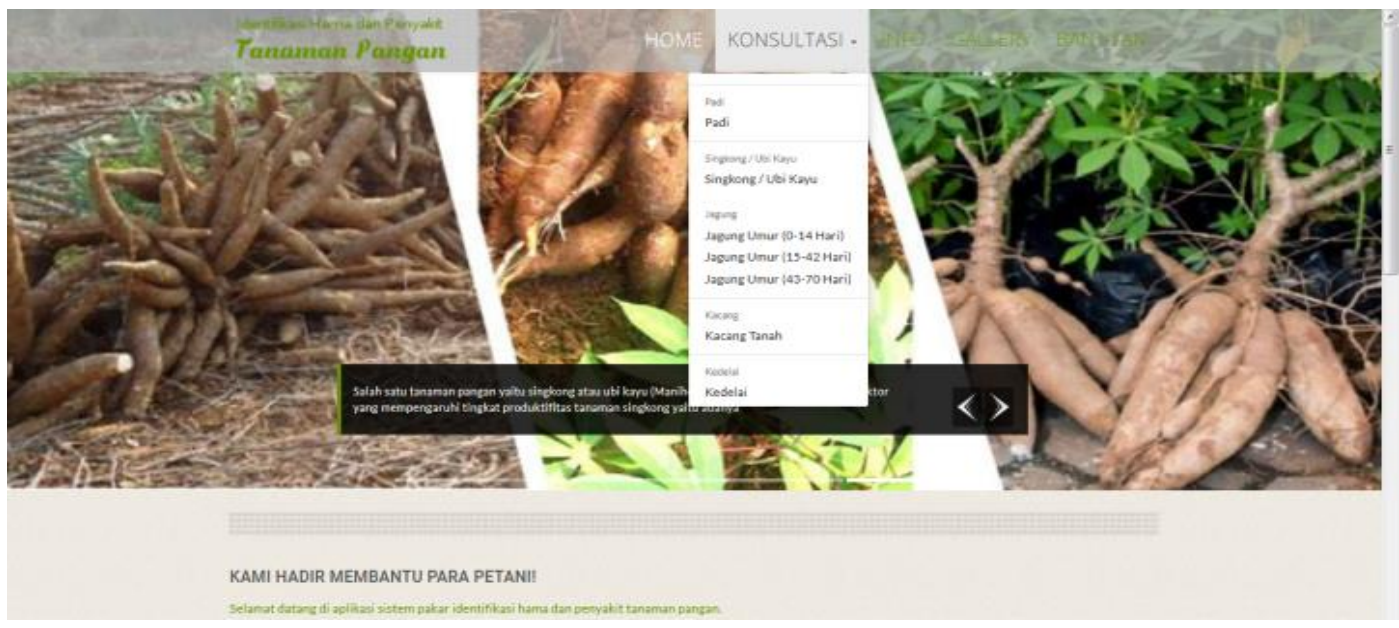

Gambar 5. Halaman Utama

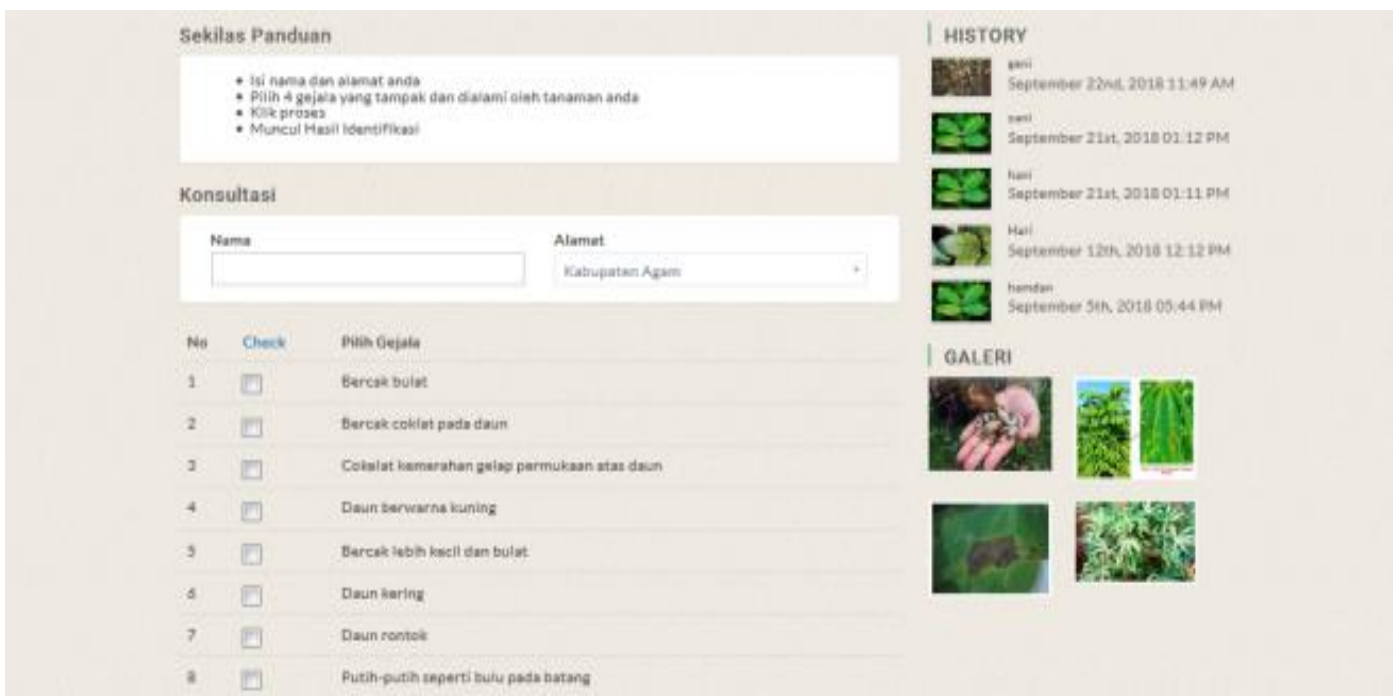

Gambar 6. Halaman Konsultasi

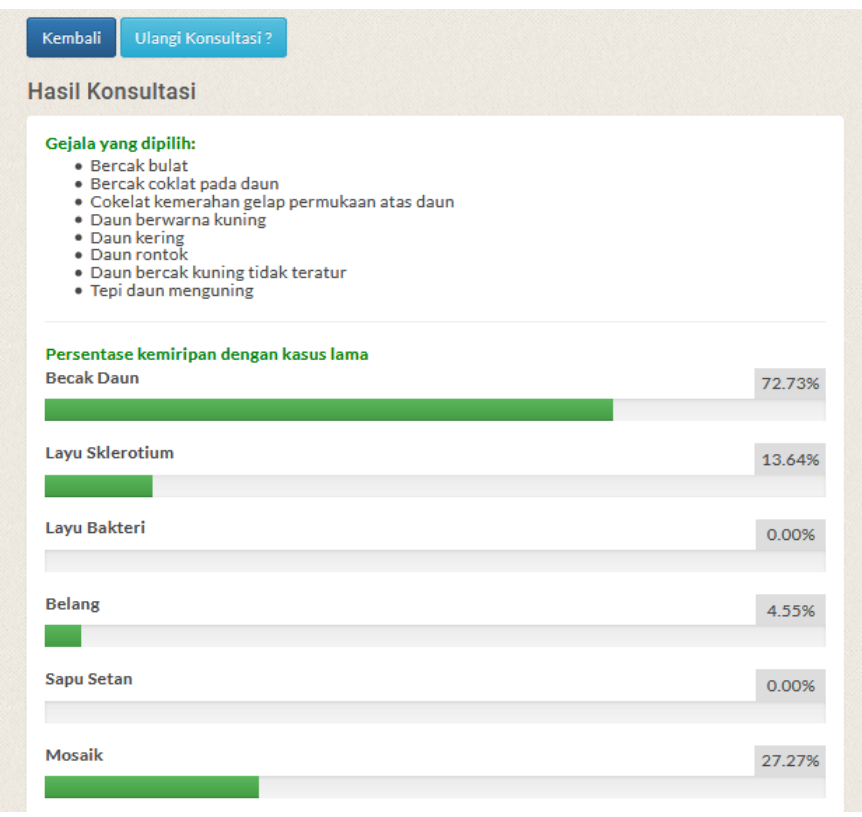

Gambar 7. Halaman Hasil Diagnosis Berdasarkan Nilai Similaritas 


\section{Kesimpulan}

Berdasarkan hasil persentase diatas, maka dapat disimpulkan bahwa hama atau penyakit yang menyerang tanaman anda : Becak Daun

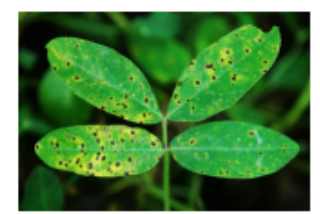

Keterangan :

Penyakit ini disebabkan oleh dua macam jamur, yaitu Cercosporidium personatum dan Cercospora arachidicola. Solusi :

1. Penyemprotan bermacam-macam fungisida yang umum.

2. Penanaman varietas kacang tanah yang tahan antara lain anoa, rusa, gajah dan kelinci.

3. Pergiliran tanaman yang tepat dapat mengurangi penyakit.

\section{Gambar 8. Hasil Diagnosis Berdasarkan Nilai Similaritas Tertinggi}

\section{B. Hasil Pengujian}

Pengujian sistem dilakukan melalui tahap menguji kasus baru dengan gejala yang sesuai dengan kasus-kasus yang tersimpan dalam basis kasus. Hasil pada tahap ini menunjukkan sistem dapat mendiagnosis 100\% secara benar penyakit tanaman pangan. Tahap selanjutnya menguji menggunakan 82 data uji yang memiliki gejala berbeda dengan kasus dalam basis kasus menggunakan ambang similaritas $\geq 70 \%$. Hasil pengujian pada tahap ini untuk tanaman padi, singkong, jagung, dan kacang tanah ditampilkan pada Tabel 5.

Dari Tabel 5, selanjutnya membuat Confusion Matrix Tabel 6 untuk pengujian sistem. Adapun keterangan Nama Penyakit pada Tabel 6 sebagai berikut: PP = Penyakit Padi; PS = Penyakit Singkong; PJ = Penyakit Jagung; PK = Penyakit Kacang Tanah.

Tabel 5. Hasil Pengujian Diagnosis Penyakit Tanaman Pangan

\begin{tabular}{llll}
\hline No. & Jenis Penyakit Tanaman Pangan & Data Uji & Diagnosis Benar \\
\hline 1 & Padi & 16 & 13 \\
2 & Singkong & 10 & 7 \\
3 & Jagung & 20 & 15 \\
4 & Kacang Tanah & 36 & 29 \\
\hline Total & 82 & 64 \\
\hline
\end{tabular}

Tabel 6. Confusion Matrix

\begin{tabular}{|c|c|c|c|c|c|c|c|}
\hline \multirow[t]{3}{*}{ Jenis } & \multirow{3}{*}{$\begin{array}{l}\text { Nama } \\
\text { Penyakit }\end{array}$} & \multirow{2}{*}{\multicolumn{2}{|c|}{ Diagnosis }} & \multirow[t]{3}{*}{ Jenis } & \multirow{3}{*}{$\begin{array}{l}\text { Nama } \\
\text { Penyakit }\end{array}$} & \multirow{2}{*}{\multicolumn{2}{|c|}{$\begin{array}{l}\text { Jumlah } \\
\text { Diagnosis }\end{array}$}} \\
\hline & & & & & & & \\
\hline & & $\begin{array}{l}\text { Benar } \\
\text { (TP) }\end{array}$ & $\begin{array}{l}\text { Salah } \\
(\mathrm{FP})\end{array}$ & & & $\begin{array}{l}\text { Salah } \\
(\mathrm{FN})\end{array}$ & $\begin{array}{l}\text { Benar } \\
(\mathrm{TN})\end{array}$ \\
\hline \multirow[t]{4}{*}{ Penyakit Tanaman Pangan } & PP & 16 & 3 & \multirow{4}{*}{$\begin{array}{l}\text { Bukan Penyakit Tanaman } \\
\text { Pangan }\end{array}$} & PP & 0 & 0 \\
\hline & PS & 10 & 3 & & PS & 0 & 0 \\
\hline & PJ & 15 & 5 & & PJ & 0 & 0 \\
\hline & PK & 29 & 7 & & PK & 0 & 0 \\
\hline
\end{tabular}

Tabel 7. Hasil Perhitungan Nilai Sensitivitas dan Akurasi

\begin{tabular}{lll}
\hline Diagnosis Penyakit & Sensitivitas (\%) & Akurasi (\%) \\
\hline Padi & 100 & 81.25 \\
Singkong & 100 & 70 \\
Jagung & 100 & 75 \\
Kacang Tanah & 100 & 80.56 \\
\hline Rata-rata & 100 & 76,70 \\
\hline
\end{tabular}

Berdasarkan hasil pengujian diperoleh nilai sensitivitas sebesar $100 \%$, sedangkan rata-rata akurasi sebesar 76, 74\%. Hasil ini menunjukkan bahwa sistem telah dapat bekerja secara baik dalam mendiagnosis penyakit tanaman pangan (padi, singkong, jagung, dan kacang tanah). 


\section{KESIMPULAN}

Dari uraian di atas dapat disimpulkan bahwa penelitian ini telah menghasilkan sistem pakar diagnosis penyakit tanaman pangan dengan menerapkan Case-based Reasoning (CBR) dengan cara mengukur kesamaan kasus yang baru dengan kasus yang tersimpan pada basis kasus. Berdasarkan hasil pengujian diperoleh nilai sensitivitas sebesar $100 \%$, sedangkan rata-rata akurasi sebesar 76 , $74 \%$. Hasil ini menunjukkan bahwa sistem telah dapat bekerja secara baik dalam mendiagnosis penyakit tanaman pangan (padi, singkong, jagung, dan kacang tanah).

\section{DAFTAR PUSTAKA}

[1] H. Semangun, "Penyakit-Penyakit Tanaman Pangan Di Indonesia. Yogyakarta.” Gajah Mada University Press, 2008.

[2] T. Penyusun, "Database Ketahanan Pangan Sumatera Barat Tahun 2014," Badan Ketahanan Pangan Sumatera Barat, 2015.

[3] V. Sutojo, "T; Mulyanto, Edi; Suhartono," Kecerdasan Buatan, 2011.

[4] S. K. Pal and S. C. K. Shiu, Foundations of soft casebased reasoning, vol. 8. John Wiley \& Sons, 2004.

[5] E. T. L. Kusrini, "Algoritma data mining," Yogyakarta Andi Offset, 2009.

[6] J. Kuswanto, "Sistem Pakar Untuk Perlindungan Tanaman Padi Menggunakan Metode Forward Chaining," Edutic-Scientific J. Informatics Educ., vol. 7, no. $1,2020$.
[7] N. Ahmad, "Metode Forward Chaining untuk Deteksi Penyakit Pada Tanaman Kentang," JINTECH, vol. 1, no. 2, pp. 7-20, 2020.

[8] E. Septriani and Y. Mukti, "Sistem Pakar Diagnosa Hama Pada Tanaman Cabai Menggunakan Metode Forward Chaining Di Dinas Pertanian Kota Pagar Alam," J. Ilm. BETRIK Besemah Teknol. Inf. dan Komput., vol. 11, no. 3, pp. 184-195, 2020.

[9] S. Suyono, R. Wati, and T. Susilowati, "Sistem Pakar Diagnosa Penyakit dan Hama pada Tanaman Jeruk Nipis Menggunakan Metode Forward dan Backward Chainning Berbasis Visual Basic 6.0," Expert J. Manaj. Sist. Inf. dan Teknol., vol. 10, no. 1, 2020.

[10] M. Minarni and A. Fadhillah, "Expert System in Detecting Rice Plant Diseases Using Certainty Factor," J. Dyn. (International J. Dyn. Eng. Sci., vol. 2, no. 1, 2017.

[11] L. Pasaribu, "Sistem Pakar Mendiagnosa Hama dan Penyakit Tanaman Mentimun Menggunakan Metode Naïve Bayes," Pelita Inform. Inf. dan Inform., vol. 7, no. 3, pp. 416-420, 2019.

[12] I. Warman and W. Handayani, "Comparison of Case-Based Reasoning and Dempster Shafer on Expert System of Cassava Disease Identification," in MATEC Web of Conferences, 2018, vol. 215.

[13] I. H. Witten, E. Frank, M. A. Hall, and C. J. Pal, "Practical machine learning tools and techniques," Morgan Kaufmann, p. 578, 2005. 